\title{
TBX5 wt Allele
}

National Cancer Institute

\section{Source}

National Cancer Institute. TBX5 wt Allele. NCI Thesaurus. Code C92149.

Human TBX5 wild-type allele is located in the vicinity of 12 q24.1 and is approximately 55

$\mathrm{kb}$ in length. This allele, which encodes T-box transcription factor T BX5 protein, plays a

role in both transcription and mesoderm differentiation. Mutation of the gene is associated with Holt-Oram syndrome. 